\title{
HUBUNGAN KARAKTERISTIK IBU DENGAN KELENGKAPAN KUNJUNGAN NEONATUS
}

\author{
Fanny Ayudia ${ }^{1}$ \\ ${ }^{2}$ Akademi Kebidanan Alifah Padang \\ Email: fannyayudia@yahoo.co.id
}

\begin{abstract}
ABSTRAK
Jumlah kematian bayi kota Padang pada tahun 2014 tercatat 109 kasus. Penurunan angka kematian neonatal dapat dicapai dengan memberikan pelayanan kesehatan sejak bayi dalam kandungan, hingga masa neonatal (Kemenkes RI, 2010). Kunjungan neonatus terendah di kota Padang yaitu di Puskesmas Alai sebanyak 68\% dari target 91\%. Tujuan dari penelitian ini yaitu mengetahui adanya hubungan karakteristik ibu dengan cakupan kunjungan neonates

Jenis penelitian iniadalah penelitian Analitik dengan desain penelitian CrossSectional Study.Penelitian dilakukan bulan November 2015 - Agustus 2016. Pengumpulan data dilakukan dari 13 Juni- 18 Juli 2016. Populasi yaitu ibu yang berkunjung ke Puskesmas Alai sebanyak 47 orang. Pengambilan sampel dengan teknik Accidental Sampling. Datadiambil menggunakan kuisioner, dianalisa secara bivariat, dan diolah secara komputerisasi.

Hasil penelitian menunjukan ibu dengan pendidikan rendah sebanyak 48,9\%, multipara sebanyak $74.5 \%$, ibu bekerja 40,4\%, dan cakupan KN3 hanya 55,3\%. Terdapat hubungan yang bermakna antara status pendidikan, paritas dan kelengkapan kunjungan neonatus, dengan masing-masing $\mathrm{p}=0,027, \mathrm{p}=0,05$. Sedangkan tidak terdapat hubungan yang bermakna antara status pekerjaan ibu dengan kelengkapan kunjungan neonatus dengan $\mathrm{p}=0,554$

Untuk mengurangi angka kematian dan mencegah komplikasi pada neonatus diperlukan kerjasama antara petugas kesehatan dan masyarakat. Diharapkan dengan hasil penelitian ini dapat mendorong masyarakat dan petugas kesehatan untuk melaksanakan kunjungan neonatus dengan lebih maksimal
\end{abstract}

\section{Kata Kunci : Karakteristik ibu, Kunjungan Neonatus}

The number of infant deaths in Padangin 2014 was recorded 109 cases. Decrease in neonatal mortality can be achieved by providing health services since the baby in the womb, until the neonatal period (Ministry of Health RI, 2010). The lowest neonate visit in the of Padang is in Puskesmas Alai $68 \%$ of the target 91\%. The purpose of this research is to know the relationship of mother characteristics with coverage of neonate visit

The type of this research is analytical research with cross sectional study design. The study was conducted in November 2015 - August 2016. The study was conducted from 13 June to 18 July 2016. The population of mothers who visited Puskesmas Alai as many as 47 people. Sampling using Accidental Sampling technique. Data were collected using questionnaires, analyzed bivariately, and computerized.

The result of research showed that the mother with low education was 48,9\%, Multipara74,5\%, working mother 40,4\%, and KN3 coverage only 55,3\%. There was a significant correlation between education status, parity and completeness of neonatal visit, with $p=0,027, p=0,05$ respectively. While there is no significant relationship between maternal job status with completeness of neonate visit with $p=0,554$.

To reduce mortality and prevent complications in the neonate requires cooperation between health workers and the public. It is hoped that with the results of this study can encourage the community and health workers to carry out the visit of the neonate with more leverage

Keywords: Characteristics of the mother, Neonates Visit 


\section{PENDAHULUAN}

Neonatus atau Bayi Baru Lahir adalah masa kehidupan pertama di luar rahim sampai dengan usia 28 hari, dimana terjadi perubahan yang sangat besar dari kehidupan didalam rahim menjadi diluar rahim (Muslihatun, 2010). Kehidupan padamasa neonatus ini sangat rawan oleh karena memerlukan penyesuaianfisiologik agar bayi di luar kandungan dapat hidup sebaik-baiknya (Dwienda). Masalah terbesar kematian neonatus terjadi pada 24 jam pertama kehidupan, minggu pertama bulan pertama.

Salah satu indikator untuk mengetahui derajat kesehatan masyarakat adalah Angka Kematian Bayi (AKB). Berdasarkan hasil Survey Demografi dan Kesehatan Indonesia (SDKI) tahun 2012, Angka kematian bayi saat ini masih tergolong tinggi yaitu mencapai 32 per 1000 kelahiran hidup. Angka tersebut lebih rendah dari tahun 2009 yang tercatat mencapai 34/1000 kelahiran hidup . Berdasarkan Profil Kesehatan Kota Padang 2013 Jumlah Kematian bayi tercatat sebanyak 102 kasus. Jumlah kematian bayi sekota Padang meningkat pada tahun 2014 yaitu tercatat sebanyak 109 kasus.

Penurunan Angka Kematian Neonatal memerlukan upaya bersama tenaga kesehatan dengan melibatkan dukun bayi, keluarga dan masyarakat dalam memberikan pelayanan kesehatan yang berkualitas bagi ibu dan bayi baru lahir. Untuk mengukur keberhasilan penerapan intervensi yang efektif dan efisien, dapat di monitor melalui indikator cakupan pelayanan yang mencerminkan jangkauan dan kualitas pelayanan kesehatan bayi baru lahir. Penurunan angka kematian neonatal dapat dicapai dengan memberikan pelayanan kesehatan yang berkualitas dan berkesinambungan sejak bayi dalam kandungan, saat lahir hingga masa neonatal.

Berdasarkan penelitian sebelumnya oleh Tuti, 2009 di kota Tais didapatkan $61 \%$ kunjungan neonatus tidak lengkap. Sedangkan hasil penelitian Anggarsih tahun 2010 di kabupaten Way kanan, didaptkan 58,8 \% umur ibu bekerja sebagai ibu rumah tangga,54,9\% berpendidikan dasar dan $47 \%$ memiliki paritas grandemultipara.

\begin{tabular}{ccc}
\hline Tingkat pendidikan & $\mathrm{f}$ & $\%$ \\
\hline Rendah & 23 & 48,7 \\
Tinggi & 24 & 51,1 \\
\hline Total & 47 & 100,0
\end{tabular}

Data yang didapat dari Dinas Kesehatan Kota Padang, pada tahun 2015 cakupan kunjungan neonatus lengkap kota Padang yaitu 94,4\%. Cakupan kunjungan neonatus lengkap di kota Padang terendah yaitu diwilayah kerja Puskesmas Alai yaitu sebanyak $68 \%$ dari target yang harus dicapai tahun 2015 yaitu $91 \%$.

Berdasarkan data yang didapatkan, peneliti tertarik untuk meneliti tentang "Hubungan Karakteristik Ibu dengan Kelengkapan Kunjungan Neonatus di Puskesmas Alai Tahun 2016

\section{METODA PENELITIAN}

Penelitian ini merupakan penelitian analitik dengan pendekatancross sectional study, untuk mengetahui Hubungan Karakteristik ibu dengan kelengkapan kunjungan neonatus di Puskesmas alai.

Populasi dalam penelitian ini adalah iibu yang berkunjung ke puskesmas alai dengan usia bayi $>28$ hari.

Sampel dalam penelitian ini sebanyak 47 responden, dengan teknik pengambilan sampel counsecutive sampel. Lokasi yang dipilih dalam penelitian ini adalah di Puskesmas Alai Padang dilakukan mulai pada bulan November 2015 sampai Agustus 2016.

HASIL

\section{A. Analisis Univariat}

\subsection{Karakteristik Responden Menurut Tingkat Pendidikan}

Distribusi frekuensikarakteristik ibu menurut tingkat pendidikan sebagai berikut :

Tabel 3.1

\section{Distribusi Frekuensi Karakteristik Responden menurut Tingkat Pendidikan}

Berdasarkan tabel 3.1 diketahui, dari 47 responden yang memiliki tingkat pendidikan rendah sebanyak 23 orang $(48,9 \%)$. 


\subsection{Karakteristik Responden menurut Paritas}

Distribusi Frekuensi Karakteristik Ibu menurut paritas dapat dilihat pada tabel 3.2 :

Tabel 3.2

\section{Distribusi Frekuensi Karakteristik Responden menurut Paritas di Puskesmas Alai}

Berdasarkan tabel 3.2 diketahui, dari 47 responden yang multipara sebanyak 35 orang $(74,5 \%)$

\subsection{Status Pekerjaan Ibu}

Distribusi Frekuensi Status Pekerjaan Ibu di Puskesmas Alai tahun 2016 dapat dilihat pada tabel 3.3 :

\section{Tabel 3.3}

\section{Distribusi Frekuensi Karakteristik Responden menurut Status Pekerjaan}

Berdasarkan tabel 3.3 didapatkan, dari 47 responden yang memiliki status bekerja sebanyak 19 orang $(40,4 \%)$.

\begin{tabular}{|c|c|c|c|c|c|c|}
\hline \multirow{3}{*}{$\begin{array}{c}\text { Status } \\
\text { Bekerja }\end{array}$} & \multicolumn{4}{|c|}{$\mathrm{KN}$} & \multirow{3}{*}{ Total } & \multirow{3}{*}{$\%$} \\
\hline & \multicolumn{2}{|c|}{ Lengkap } & \multicolumn{2}{|c|}{ Tidak lengkap } & & \\
\hline & $f$ & $\%$ & $\mathrm{f}$ & $\%$ & & \\
\hline Kerja & 7 & $\begin{array}{c}36, \\
8\end{array}$ & 12 & 63,2 & 19 & 100 \\
\hline $\begin{array}{l}\text { Tidak } \\
\text { kerja }\end{array}$ & 14 & 50 & 14 & 50 & 28 & 100 \\
\hline
\end{tabular}

\subsection{Kunjungan Neonatus Lengkap}

Distribusi frekuensiKunjungan Neonatus sebagai berikut :

\section{Distribusi Frekuensi Kunjungan Neonatus Lengkap di Puskesmas Alai}

Berdasarkan tabel 3.4 diketahui, dari 47 responden yang tidak melakukan kunjungan neonatus lengkap sebanyak 26 orang $(55,3 \%)$.

\section{B. Analisa Bivariat}

\begin{tabular}{|c|c|c|c|}
\hline 3.4 Hubungan & Pendidikan & dengan & Kelengkapan \\
\hline Paritas & $\mathrm{f}$ & & $\%$ \\
\hline Primipara & 12 & & 25,5 \\
\hline Multipara & 35 & & 74,5 \\
\hline Total & 47 & & 100,0 \\
\hline
\end{tabular}

Kunjungan Neonatus.

Distribusi Frekuensi Hubungan Pendidikan dengan kelengkapan Kunjungan Neonatus dapat dilihat pada tabel dibawah ini :

Tabel 3.4

\begin{tabular}{ccc}
\hline Pekerjaan & Jumlah & $\%$ \\
\hline Bekerja & 28 & 59,6 \\
Tidak Bekerja & 19 & 40,4 \\
\hline Jumlah & 47 & 100
\end{tabular}

Hubungan Pendidikan dengan kelengkapan kunjungan
Neonatus

$\mathrm{p}=0,027$

Dari tabel 4.5 dapat diketahui dari 23 responden yang memiliki tingkat pendidikan rendah terdapat 17 responden $(73,9 \%)$ tidak melakukan kunjungan neonatus lengkap sedangkan dari 24 responden yang memiliki tingkat

\begin{tabular}{ccc}
\hline Kategori & $\mathrm{f}$ & $\%$ \\
\hline Tidak lengkap & 26 & 55,3 \\
Lengkap & 21 & 44,7 \\
\hline Total & 47 & 100,0 \\
\hline
\end{tabular}

Tabel 3.4 
pendidikan tinggi sebanyak 9 responden (37,5\%) tidak melakukan kunjungan neonatus lengkap. pada hasil uji statistik didapatkan $p$ value $=0,027(p$ value $<0,05)$ sehingga dapat dikatakan terdapat hubungan yang bermakna antara tingkat pendidikan dengan cakupan kunjungan neonatus lengkap

\subsection{Hubungan Karakteristik Responden Menurut Paritas dengan Cakupan Kelengkapan Kunjungan Neonatus.}

Distribusi Frekuensi Hubungan Karakteristik ibu menurut paritas dengan cakupan kelengkapan kunjungan neonatus di puskesmas alai Padang Tahun 2016 dapat dilihat pada tabel dibawah ini :

Tabel 3.5

\section{Hubungan Karakteristik Responden Menurut Paritas} dengan Cakupan Kelengkapan Kunjungan Neonatus

\begin{tabular}{ccccccc}
\hline \multirow{3}{*}{ Paritas } & \multicolumn{4}{c}{ KN } & & \\
\cline { 2 - 5 } & Lengkap & \multicolumn{2}{c}{$\begin{array}{c}\text { Tidak } \\
\text { lengkap }\end{array}$} & Total & $\%$ \\
\cline { 2 - 5 } & $\mathrm{f}$ & $\%$ & $\mathrm{f}$ & $\%$ & & \\
\hline Multipara & 3 & 25 & 9 & 75 & 12 & 100 \\
Primipara & 25 & 60 & 10 & 40 & 35 & 100 \\
\hline $\mathrm{p}=0,005$ & & & & & &
\end{tabular}

Dari tabel 3.5 dapat diketahui dari 12 responden multipara terdapat 9 responden $(75 \%)$ tidak melakukan kunjungan neonatus lengkap sedangkan dari 35 responden primipara sebanyak 10 responden (40\%) tidak melakukan kunjungan neonatuslengkap. Pada hasil uji statistik didapatkan $p$ value $=0,005(p$ value $<0,05)$ sehingga dapat dikatakan terdapat hubungan yang bermakna antara paritas dan cakupan kunjungan neonatus lengkap

3.6 Hubungan Karakteristik Responden Menurut Pekerjaan dengan Cakupan Kelengkapan Kunjungan Neonatus.
Distribusi Frekuensi Hubungan Karakteristik ibu menurut pekerjaan dengan cakupan kelengkapan kunjungan neonatus di puskesmas alai Padang Tahun 2016 dapat dilihat pada tabel dibawah ini :

Tabel 3.5

Hubungan Karakteristik Responden Menurut Pekerjaan dengan Cakupan Kelengkapan Kunjungan Neonatus

\begin{tabular}{|c|c|c|c|c|c|c|}
\hline \multirow{3}{*}{$\begin{array}{c}\text { Tingkat } \\
\text { pendidikan }\end{array}$} & \multicolumn{4}{|c|}{$\mathrm{KN}$} & \multirow{3}{*}{ Total } & \multirow{3}{*}{$\%$} \\
\hline & \multicolumn{2}{|c|}{ Lengkap } & \multicolumn{2}{|c|}{$\begin{array}{c}\text { Tidak } \\
\text { lengkap }\end{array}$} & & \\
\hline & $\mathrm{f}$ & $\%$ & $\mathrm{~F}$ & $\%$ & & \\
\hline Tinggi & 15 & 62,5 & 9 & 37,5 & 24 & 100 \\
\hline Rendah & 6 & 26,1 & 17 & 73,9 & 23 & 100 \\
\hline
\end{tabular}

Dari tabel 3.6 dapat diketahui dari 19 responden yang memiliki status bekerja terdapat 12 responden $(63,2 \%)$ tidak melakukan kunjungan neonatus lengkap sedangkan dari 28 responden yang memiliki status tidak bekerja sebanyak 14 responden $(50 \%)$ tidak melakukan kunjungan neonatus lengkap. Pada hasil uji statistik didapatkan $p$ value $=0,554$ ( $p$ value $>0,05$ ) sehingga dapat disimpulkan bahwa tidak terdapat hubungan yang bermakna antara status pekerjaan dengan cakupan kunjungan neonatus lengkap.

\section{PEMBAHASAN}

\section{Analisa Univariat}

\subsection{Tingkat Pendidikan}

Berdasarkan tabel 3.1 diketahui responden yang memiliki tingkat pendidikan dasar yaitu sebanyak 23 orang $(48,9 \%)$.

Hal ini sejalan dengan penelitian yang dilakukan oleh Anggarsih Sri Wahyuni pada tahun 2010 di Desa Gunung Katun Kabupaten Way Kanan dimana didapatkan ibu yang memiliki pendidikan dasar sebanyak 28 orang $(54,9 \%)$.

Tingkat pendidikan juga mempunyai hubungan dengan tingkat kesehatan. Latar belakang pendidikan seseorang 
berhubungan dengan tingkat pengetahuan, jika tingkat pengetahuan ibu baik maka diharapkan status kesehatan ibu dan balitanya juga baik.

Peneliti berasumsi bahwa, tingginya tingkat pendidikan responden di Puskesmas Alai dipengaruhi oleh letak geografis Kelurahan Alai dan kondisi ekonomi sekarang. Dimana Alai terletak dipusat kota sehingga memudahkan akses didalam bidang pendidikan, dan status sosial ekonomi, dimana orang dengan status sosial ekonomi yang menengah keatas, seseorang bisa menempuh pendidikan yang lebih tinggi, di Kelurahan Alai sendiri sebagian besar responden memiliki latar belakang SMA, dimana dengan memiliki latar belakang SMA mereka menganggap mudah untuk memiliki pekerjaan.

\subsection{Paritas}

Berdasarkan tabel 3.2 diketahui responden yang multipara sebanyak 35 orang $(75 \%)$

Hasil penelitian ini berbeda dengan hasil penelitian yang dilakukan oleh Anggarsih Sri Wahyuni pada tahun 2010 di Desa Gunung Katun Kabupaten Way Kanan dimana didapatkan ibu yang memiliki paritas grandemultipara kurang dari separohnya yaitu sebanyak 24 orang (47\%). Perbedaan hasil disebabkan oleh perbedaan jumlah sampel, dimana Anggarsih mengambil seluruh populasi yaitu 51 orang untuk dijadikan sampel dikarenakan letak desa Gunung Katun didaerah terpencil dan memiliki jumlah penduduk yang sedikit.

Kehamilan dan persalinan pada paritas tinggi atau grande multi para adalah ibu hamil dan melahirkan 4 kali lebih, paritas tinggi merupakan paritas rawan oleh karena paritas tinggi banyak kejadian-kejadian obstetrik. Paritas adalah jumlah persalinan yang pernah dialami oleh wanita. Indeks kelamilan resiko tinggi adalah paritas $\geq 4$ (Manuaba,2010)

Peneliti berasumsi bahwa, banyaknya jumlah ibu yang memiliki paritas tinggi salah satunya dipengaruhi oleh latarbelakang budaya. Latar belakang budaya yang mempengaruhi paritas antara lain adalah anggapan bahwa semakin banyak anak semakin banyak rezeki. sangat diperlukan adanya fasilitas kesehatan yang layak terutama didaerah terpencil sebagai sarana edukasi melalui pendekatan budaya bagi masyarakat mengenai program keluarga berencana.

\subsection{Status Pekerjaan}

Berdasarkan tabel 3.3 responden yang memiliki status bekerja sebanyak 19 orang (40,4\%).

Sejalan dengan hasil penelitian yang dilakukan oleh Anggarsih dimana didapatkan ibu yang memiliki status IRT lebih dari separohnya yaitu sebanyak 30 orang $(58,8 \%)$.

Bagi wanita pekerja, bagaimanapun mereka juga ibu rumah tangga yang sulit lepas begitu saja dari lingkungan keluarga. Karenanya dalam meniti karier, wanita mempunyai beban dan hambatan yang lebih berat dibanding rekan prianya. Dalam arti, wanita terlebih dahulu harus mengatasi urusan keluarga- suami, anak, dan hal-hal lain yang menyangkut urusan rumah tangganya (Anoraga,2014)

Dengan ini peneliti berasumsi bahwa, tuntutan ekonomi ataupun gaya hidup modern mendorong wanita terjun kedunia kerja untuk membantu suami memenuhi kebutuhan finansial. Akan tertapi, banyak juga wanita yang lebih memilih untuk tetap dirumah mengurus rumah tangga, merawat dan memantau tumbuh kembang anak.

\subsection{Kunjungan Neonatus}

Berdasarkan tabel 3.4 responden yang tidak melakukan kunjungan neonatus lengkap sebanyak 26 orang $(55,3 \%)$.

Hasil penelitian ini sejalan dengan penelitian yang dilakukan oleh Anggarsih Sri Wahyuni pada tahun 2010 di Desa Gunung Katun Kabupaten Way Kanan, bahwasanya cakupan kunjungan neonatus yaitu sebanyak 72 orang $(58,8 \%)$

Tujuan dari kunjungan neonatus, yaitu melakukan pemeriksaan ulang pada bayi baru lahir,meninjau penyuluhan dan paedoman antisipasi bersama orangtua, mengidentifikasi gejala penyakit, serta mendidik dan mendukung orangtua (Siwi, Walyani.2014).

Peneliti berasumsi bahwa, terdapat banyak faktor yang membuat kunjungan neontaus lengkap di Puskesmas Alai tidak memuhi target. Selain dari karakteristik ibu , tenaga kesehatan juga memiliki peran penting dalam berjalannya salah satu program KIA ini. Misalnya, tenaga kesehatan yang kurang optimal dalam memberi penyuluhan kepada masyarakat tentang pentingnya melakukan kunjungan neonatus lengkap atau tenaga kesehatan yang jarang melakukan kunjungan rumah untuk melakukan pemeriksaan neonatus. 


\subsection{Hubungan Karakteristik ibu menurut pendidikan dengan cakupan kunjungan neonatus lengkap}

Dari tabel 4.5 dapat diketahui dari 23 responden yang memiliki tingkat pendidikan rendah terdapat 17 responden $(73,9 \%)$ tidak melakukan kunjungan neonatus lengkap sedangkan dari 24 responden yang memiliki tingkat pendidikan tinggi sebanyak 9 responden (37,5\%) tidak melakukan kunjungan neonatus lengkap. pada hasil uji statistik didapatkan $p$ value $=0,027$ ( $p$ value $<0,05)$ sehingga dapat dikatakan terdapat hubungan yang bermakna antara tingkat pendidikan dengan cakupan kunjungan neonatus lengkap.

Hasil penelitian ini sangat jauh berbeda dengan penelitian yang dilakukan oleh Hestri Suryaningsih yang mana memperoleh hasil bahwa tidak ada hubungan yang bermakna antara tingkat pendidikan dengan perilaku kunjungan Bayi ke Posyandu. Hasil penelitian berbeda karena pada penelitian Hestri, ibu dengan tingkat pendidikan tinggi yang melakukan kunjunganlebih rendah dibandingkan dengan ibu yang memiliki tingkat pendidikan rendah.

Pendidikan merupakan bagian hakiki dari kehidupan. Pendidikan merupakan usaha manusia dan masyarakat untuk menjawab tantangan kehidupan. Pendidikan secara umum adalah segala upaya yang direncanakan untuk mempengaruhi orang lain baik individu, kelompok atau masyarakat sehingga mereka melakukan apa yang diharapkan oleh pelaku pendidikan(Notoatmodjo,2007).

Tidak dapat dipungkiri bahwa makin tinggi pendidikan seseorang semakin mudah pula mereka menerima informasi, dan pada akhirnya makin banyak pula pengetahuan yang dimilikinya. Sebaliknya jika tingkat pendidikan seseorang rendah, akan menghambat perkembangan perilaku seseorang terhadap penerimaan, informasi dan nilai-nilai yang baru diperkenalkan termasuk perilaku kesehatan (Mubarak et al., 2007).

Dengan demikian, peneliti berasumsi bahwa ibu yang memiliki tingkat pendidikan tinggi memiliki kesadaran yang cenderung lebih tinggi dibandingkan dengan ibu yang memiliki tingkat pendidikan rendah tentang pentingnya memeriksakan kesehatan bayi baru lahir. Ibu dengan pendidikan tinggi akan memiliki pengetahuan luas serta berkeinginan untuk meningkatkan kualitas kesehatan bayinya dan menggali informasi lebih banyak tentang kesehatan bayi baru lahir.

\subsection{Hubungan Karakteristik Ibu menurut Paritas dengan cakupan Kelengkapan kunjungan Neonatus.}

Dari tabel 4.6 dapat diketahui dari 12 responden multipara terdapat 9 responden $(75 \%)$ tidak melakukan kunjungan neonatus lengkap sedangkan dari 35 responden primipara sebanyak 10 responden $(40 \%)$ tidak melakukan kunjungan neonatuslengkap. Pada hasil uji statistik didapatkan $p$ value $=0,05(p$ value $<0,05)$ sehingga dapat dikatakan terdapat hubungan yang bermakna antara paritas dan cakupan kunjungan neonatus lengkap.

Hasil penelitian ini sangat jauh berbeda dengan penelitian yang dilakukan oleh Hestri Suryaningsih yang mana memperoleh hasil bahwa tidak ada hubungan yang bermakna antara jumlah bayi dan Balita dengan perilaku kunjungan Posyandu. Perbedaan disebabkan sebagian besar responden tidak bekerja sehingga jumlah anak tidak memiliki pengaruh besar terhadap Kunjungan Posyandu.

Menurut Akter dan Rahman yang dikutip oleh Vinda (2013) mengatakan bahwa ibu multipara dikaitkan dengan durasi mengasuh yang lebih pendek, hal ini mengarah pada jarak kelahiran yang pendek dan waktu yang singkat dalam mengurus setiap anak sehingga tuntutan waktunya untuk mengurus anak mengurangi kepedulian ibu untuk memeriksakan pertumbuhan dan perkembangan anaknya.

Dengan demikian peneliti berasumsi bahwa, ibu yang memiliki paritas tinggi atau dengan artian yang memiliki banyak anak memiliki anggapan sudah mampu melakukan perawatan bayi baru lahir dengan baik. sehingga tidak perlu lagi bantuan dari tenaga kesehatan. padahal asuhan yang diberikan pada kunjungan neonatus bukan hanya cara merawat bayi baru lahir, namun juga pememeriksaan dan perawatan untuk mencegah komplikasi yang bisa saja dialami oleh bayi baru lahir.

\subsection{Hubungan Karakteristik Ibu menurut pekerjaan dengan cakupan kelengkapan kunjungan neonatus.}

Dari tabel 4.7 dapat diketahui dari 19 responden yang memiliki status bekerja terdapat 12 responden $(63,2 \%)$ tidak melakukan kunjungan neonatus lengkap sedangkan dari 28 responden yang memiliki status tidak bekerja sebanyak 14 responden $(50 \%)$ tidak melakukan kunjungan neonatus lengkap. pada hasil uji statistik didapatkan $p$ value $=0,554$ ( $p$ value $>0,05)$ sehingga dapat disimpulkan bahwa tidak terdapat hubungan yang bermakna antara status pekerjaan dengan cakupan kunjungan neonatus lengkap.

Sejalan dengan penelitian yang dilakukan oleh Hestri Suryaningsih yang mana memperoleh hasil bahwa tidak ada hubungan yang bermakna antara pekerjaan dengan perilaku kunjungan Posyandu.

Bagi wanita pekerja, bagaimanapun mereka juga ibu rumah tangga yang sulit lepas begitu saja dari lingkungan 
keluarga. Karenanya dalam meniti karier, wanita mempunyai beban dan hambatan yang lebih berat dibanding rekan prianya. Dalam arti, wanita terlebih dahulu harus mengatasi urusan keluarga- suami, anak, dan hal-hal lain yang menyangkut urusan rumah tangganya (Anoraga,2014)

Di Indonesia, hak istimewa bagi setiap ibu agar dapat istirahat dan mengurus anak setelah melahirkan. Pemerintah telah menjamin hak setiap pekerja atau buruh perempuan untuk mendapatkan cuti melalui UU Tenaga Kerja Nomor 13 tahun 2003. Dalam UU ini, setiap pekerja berhak mendapat kesempatan selama 3 bulan untuk mengambil cuti seperti yang disebut dalam Pasal 82 yakni 1,5 bulan sebelum melahirkan dan 1,5 bulan setelah melahirkan.

Peneliti berasumsi bahwa, secara rasional ibu yang bekerja berpengaruh pada perilaku ibu untuk melakukan kunjungan ketenaga kesehatan, ibu yang bekerja lebih sibuk dengan pekerjaan sehingga tidak memiliki waktu untuk melakukan kunjungan neonatus. Namun, wanita yang berstatus kerja bukan lagi menjadi alasan untuk tidak melakukan kunjungan neonatus. Seperti yang dijelaskan pada paragraf sebelumnya, wanita diberikan cuti selama satu setengah bukan setelah melahirkan. Dengan demikian, wanita yang bekerja maupun yang tidak bekerja sama-sama memiliki waktu luang untuk melakukan kunjungan neonatus

\section{KESIMPULAN}

Dari hasil penelitian yang telah dilakukan dapat ditarik kesimpulan sebagai berikut :

1. Kurang dari separoh (48,9\%) ibu bayi $>28$ hari sampai 6 bulan memiliki tingkat pendidikan rendah di Puskesmas Alai pada tahun 2016.

2. Lebih dari separoh $(53,2 \%)$ dari ibu bayi $>28$ hari sampai 6 bulan memiliki paritas tinggi di Puskesmas Alai pada tahun 2016.

3. Kurang dari separoh $(40,4 \%)$ dari ibu bayi $>28$ hari sampai 6 bulan memiliki satatus Bekerja di Puskesmas Alai pada tahun 2016.

4. Kurang dari separoh $(44,7 \%)$ dari ibu bayi $>28$ hari sampai 6 bulan yang melakukan Kunjungan Neonatus lengkap (KN3).di Puskesmas Alai pada tahun 2016.

5. Terdapat hubungan yang signifikan antara tingkat pendidikan terhadap kelengkapan Kunjungan Neonatus di Puskesmas Alai Tahun 2016.

6. Terdapat hubungan yang signifikan antara Paritas terhadap kelengkapan Kunjungan Neonatus di Puskesmas Alai Tahun 2016.

7. Tidak terdapat hubungan yang signifikan antara Status Bekerja terhadap kelengkapan Kunjungan Neonatus di Puskesmas Alai tahun 2016.

\section{DAFTAR PUSTAKA}

1) Ai Yeyeh, Rukiyah. Yulianti Lia.2010.Asuhan Neonatus Bayi Dan Anak Balita.Jakarta:Cv Trans Info Media

2) BKKBN. (2006). Buku Saku Bagi Petugas Lapangan Program KB Nasional Materi Konseling, Jakarta. BKKBN

3) Badan Pusat Statistik. 2013. Survei Demografi dan Kesehatan Indonesia 2012. Jakarta: Badan Pusat Statistik.

4) Cunningham,2000.Http://Digilib.Unimus.Ac.Id/Files/Dis ki/123/Jtptunimus.Gdl-Aridwijaya-6585-3-Babii.Pdf.Dia kses Tanggal 24 Des 2015

5) Dinas Kesehatan Kota Padang. 2014.Laporan Tahunan Tahun 2013. Padang. :DKK.

6) Dinas Kesehatan Kota Padang.2014. Profil Kesehatan Tahun 2013 .Padang :DKK

7) Dinas Kesehatan Kota Padang.2015. Data Cakupan Kunjungan Neonatus Puskesmas Sekota Padang Tahun 2015.Padang:DKK

8) Dwienda, R Octa, dkk.2014.Buku Ajar Asuhan Bayi/Balita dan Anak Prasekolah Untuk Para Bidan.Yogyakarta:CV Budi Utama

9) Hestri Suryaningsih.2012.Faktor-Faktor Yang Berhubungan Dengan Perilaku Kunjungan Ibu Bayi Dan Balita Ke Posyandu Di Puskesmas Kemiri Muka Kota Depok Tahun 2012.Depok.Universitas Indonesia.

10) Kartikasari, Bunga Widita.Dkk.2011.Hubungan Pendidikan, Paritas, Dan Pekerjaan Ibu Dengan Statusgizi Ibu Hamil Trimester Iii Di Puskesmas Bangetayu Kecamatan Genuk Kota Semarang Tahun 2011.Semarang: Universitas Muhammadiyah.

11) Kementrian Kesehatan Republik Indonesia.2013.Riset Kesehatan Dasar Tahun 2013. Jakarta:Kemenkes RI

12) Kementrian Kesehatan Republik Indonesia.2010. Paduan Pelayanan Kesehatan Bayi Baru Lahir Berbasis Perlindungan Anak .2010. Jakarta, Kemenkes RI

13) Kementrian Kesehatan Republik Indonesia.2010.Buku Saku Pelayanan Kesehatan Neonatal 2010.Jakarta, Kemenkes RI

14) Lenner,2001.Www.Jurnalpendidikan.Com/42+Waktu-K erjanormal-Bumil

15) Manuaba, Ida Bagus.2010.Ilmu Kebidanan dan Keluarga Berencana.Jakarta:EGC

16) Mcdonald,2008.Http://Bidanku.Blogspot.Com-Paritas-Ib u-Kehamilan 
17) Muslihatun, Wafi Nur.2010.Asuhan Neonatus Bayi Dan Balita.Yogyakarta: Fitramaya

18) 17)Mubarak, Wahid Iqbal, dkk.2007.Promosi Kesehatan Sebuah Metode Pengantar Dalam Pendidikan. Yogyakarta:Graha Ilmu

19) Nanny Lia Dewi, Vivian.2013.Asuhan Neonatus Bayi Dan Anak Balita.Yogyakarta:Salemba Medika.

20) 19)Notoatmodjo, Soekidjo. 2010.Metodologi Penelitian Kesehatan.Jakarta: Rineka Cipta

21) Notoatmodjo, Soekidjo, 2010.Pendidikan Dan Prilaku Kesehatan .Jakarta: EGC

22) Prawiroharjdo. Sarwono. 2008.Ilmu Kebidanan.Jakarta:Pt.Bina Pustaka Sarwono Prawiroharjdo

23) Puskesmas Alai. Laporan Tahunan tahun 2015.Padang

24) Republik Indonesia.2003.Undang-Undang No.20 Tahun 2003 Tentang Istem Pendidikan Nasional.Sekretariat Negara.Jakarta

25) Siwi, Walyani.2014.Materi Ajar Lengkap Asuhan Kebidanan Komunitas.Yogyakarta:Pt. Pustaka Baru

26) Sugiyono.2014.Metode Penelitian Kuantitatif dan Kulalitatif. Bandung:CV. Alfabeta

27) Sri Wahyuni, Anggarsih.2010. Gambaran Faktor Yang Menyebabkan Rendahnya Cakupan Kunjungan Neonatus (KN) Di Desa Gunung Katun Kecamatan Baradatu Kabupaten Way Kanaan Tahun 2010.

28) Vinda Dwi Oktoviyanda, Helwiyah Ropi, Ai Mardhiyah. Hubungan Tingkat Pendidikan, Pekerjaan, dan Paritas Ibu dengan Usia Penyapihan pada Balita. Fakultas Keperawatan Universitas Padjadjaran (Http://Www.Ejkp.Org/Jkp/Index.Php/Jkp/Article/View/ 63/60 diakses tanggal 23 Desember 2015)

29) Yulifah, Rita. Johan Agus Yuswanto, Tri.2013.Asuhan Kebidanan Komunitas.Jakarta: Salemba Medika 